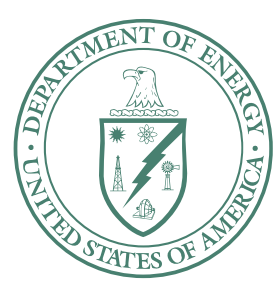

U.S. Department of Energy

Idaho Operations Office

\title{
Action Memorandum for Decommissioning of TAN-607 Hot Shop Area
}

May 2007 
DOE/ID-11322

Revision 0

\section{Action Memorandum for Decommissioning of TAN-607 Hot Shop Area}

May 2007 
Signature sheet for the Action Memorandum covering the Decommissioning of TAN-607 Hot Shop Area, Technical Support Facility, at the U.S. Department of Energy's Idaho National Laboratory. This action is conducted by the U.S. Department of Energy with the concurrence of the U.S. Environmental Protection Agency and the Idaho Department of Environmental Quality.
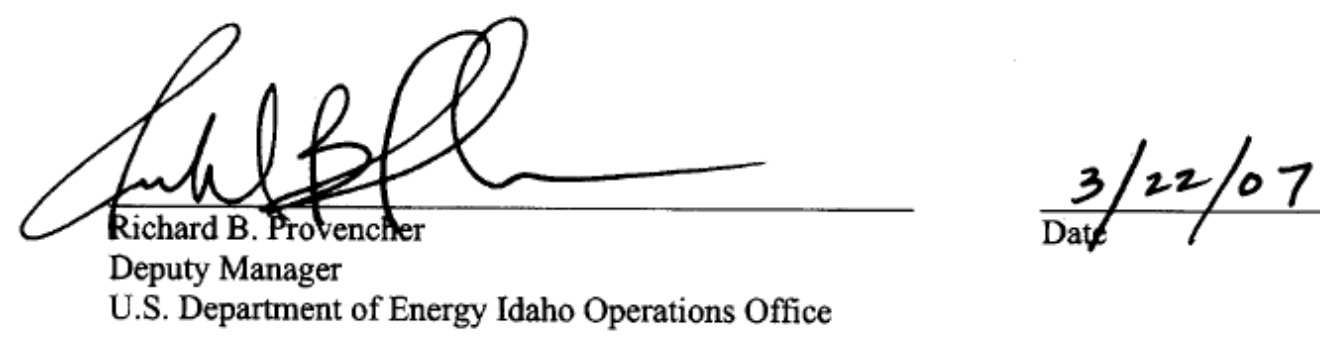

U.S. Department of Energy Idaho Operations Office 

Signature sheet for the Action Memorandum covering the Decommissioning of TAN-607 Hot Shop Area, Technical Support Facility, at the U.S. Department of Energy's Idaho National Laboratory. This action is conducted by the U.S. Department of Energy with the concurrence of the U.S. Environmental Protection Agency and the Idaho Department of Environmental Quality.

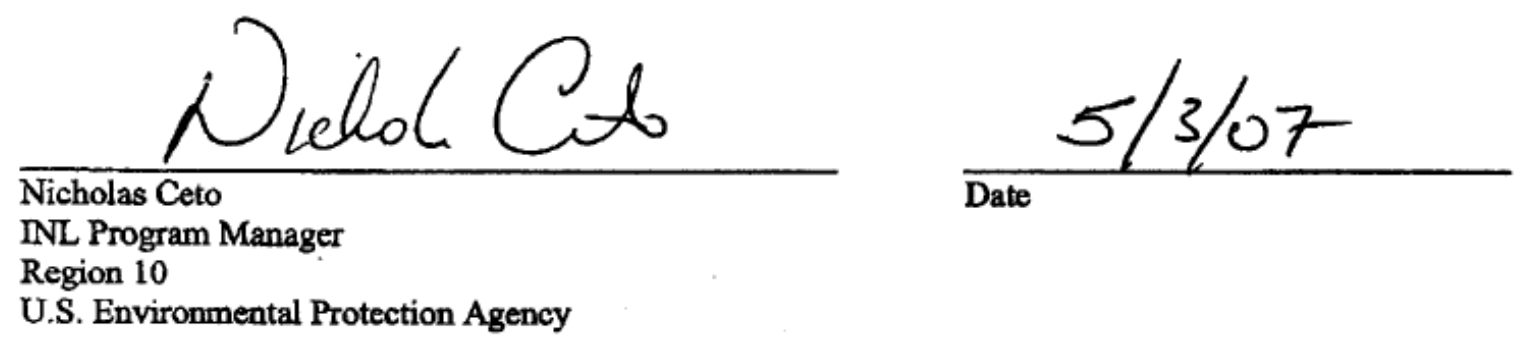



Signature sheet for the Action Memorandum covering Decommissioning of TAN-607 Hot Shop Area, Technical Support Facility, at the U.S. Department of Energy's Idaho National Laboratory. This action is conducted by the U.S. Department of Energy with the concurrence of the U.S. Environmental Protection Agency and the Idaho Department of Environmental Quality.

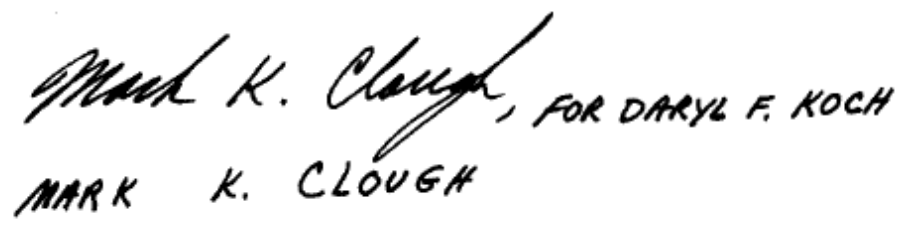

Daryl F. Koch

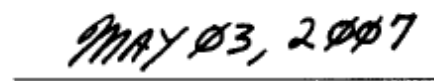

FFA/CO Manager

Date

Waste Management and Remediation Division

Idaho Department of Environmental Quality 



\section{ABSTRACT}

The Department of Energy is documenting the selection of an alternative for the TAN-607 Hot Shop Area using a Comprehensive Environmental Response, Compensation, and Liability Act non-time-critical removal action (NTCRA). The scope of the removal action is limited to TAN-607 Hot Shop Area. An engineering evaluation/cost analysis (EE/CA) has assisted the Department of Energy Idaho Operations Office in identifying the most effective method for performing the decommissioning of this structure whose mission has ended. TAN-607 Hot Shop Area is located at Test Area North Technical Support Facility within the Idaho National Laboratory Site.

TAN-607 is designated as a historical Signature Property by DOE Headquarters Advisory Council on Historic Preservation and, as such, public participation was sought through the EE/CA process to determine the final disposition of the facility. The decommissioning action will place the TAN-607 Hot Shop Area in a final configuration that will be protective of human health and the environment. Decommissioning the TAN-607 Hot Shop Area is consistent with the joint DOE and U.S. Environmental Protection Agency (EPA) Policy on Decommissioning of Department of Energy Facilities Under the Comprehensive Environmental Response, Compensation and Liability Act, which establishes the CERCLA NTCRA process as the preferred approach for decommissioning surplus DOE facilities. Under this policy, a NTCRA may be taken when DOE determines that the action will prevent, minimize, stabilize, or eliminate a risk to human health and/or the environment. When DOE determines that a CERCLA NTCRA is necessary, DOE is authorized to evaluate, select, and implement the removal action that DOE determines is most appropriate to address the potential risk posed by the release or threat of release. This action is taken in accordance with applicable authorities and in conjunction with EPA and the State of Idaho pursuant to Section 5.3 of the Federal Facility Agreement and Consent Order.

The selected alternative consists of demolishing the TAN-607 aboveground structures and components, removing belowground noninert components (e.g., wood products), and removing the radiologically contaminated debris that does not meet remedial action objectives (RAOs), as defined in the Record of Decision Amendment for the V-Tanks (TSF-09 and TSF-18) and Explanation of Significant Differences for the PM-2A Tanks (TSF-26) and TSF06, Area 10, at Test Area North, Operable Unit 1-10. Radiologically contaminated debris that does meet the RAOs will be left in the excavation created from demolition of TAN-607 and the adjacent void remaining after completion of the V-Tanks soil removal project. Waste will be disposed in the Idaho CERCLA Disposal Facility (ICDF), TAN Demolition Landfill, or suitable off-Site disposal as applicable. Upon completion of demolition, the remaining void will be backfilled with solid inert material, graded to meet the natural contour of the area and reseeded. 


\section{CONTENTS}

ABSTRACT. iii

ACRONYMS vii



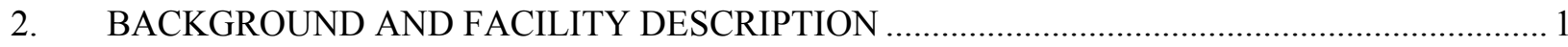

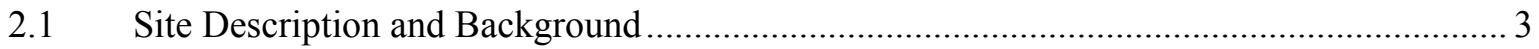

2.1.1 Test Area North Area, Specifically TAN-607 Hot Shop Area........................... 3

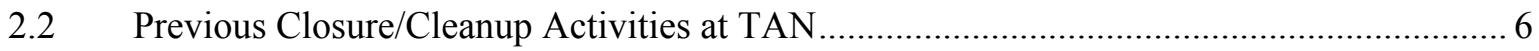

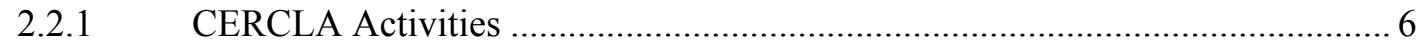

2.2.2 Voluntary Consent Order HWMA/RCRA Closure Activities ............................ 7

2.3 Current Closure/Cleanup Activities at TAN-607 Hot Shop Area ...................................... 7

3. THREAT TO PUBLIC HEALTH, WELFARE, AND/OR THE ENVIRONMENT ........................ 8



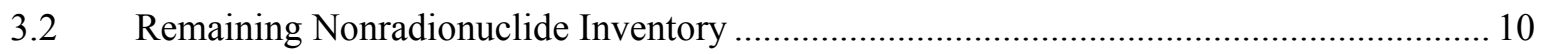

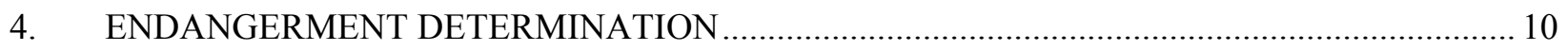

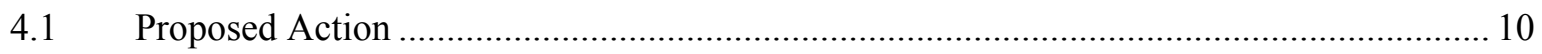

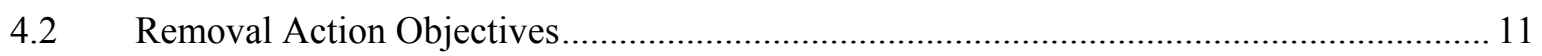

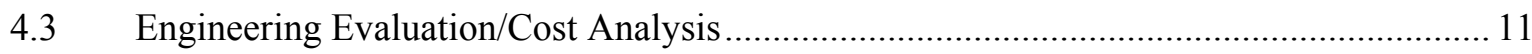

4.3.1 Alternative 1 - No Action Alternative .......................................................... 11

4.3.2 Alternative 2 - Cold, Dark, and Dry with Continued Surveillance and Monitoring......................................................................................... 12

4.3.3 Alternative 3 - Demolition, Removal, and Disposal of Building and Building Contents to Meet the Remedial Action Objectives ......................................... 12

4.4 Compliance with Environmental Regulations, Including Those That Are Applicable, or Relevant and Appropriate Requirements................................................................... 13

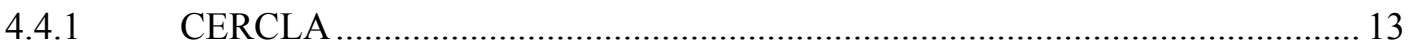

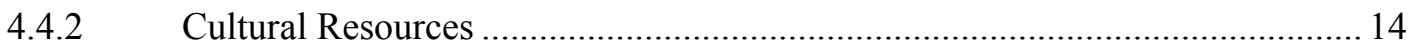

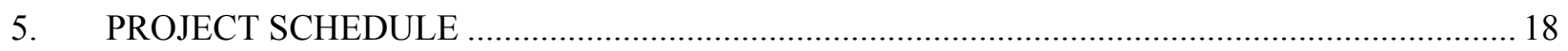



7. EXPECTED CHANGE SHOULD ACTION BE DELAYED OR NOT TAKEN .......................... 19 


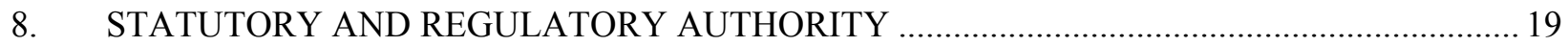

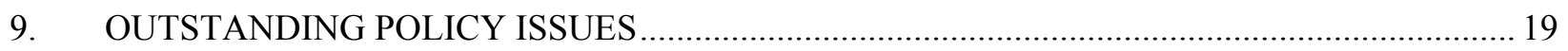

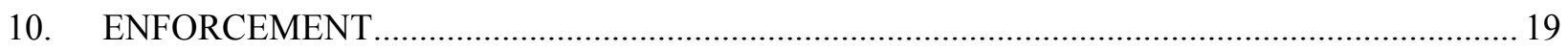



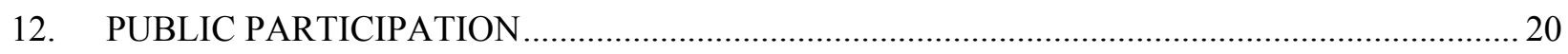

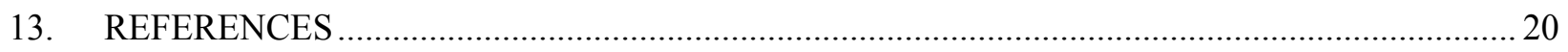

Appendix A, Responses to Significant Comments on the TAN-607 Hot Shop Area Decommissioning. A-1

Appendix B, Citizens Advisory Board Comments ...................................................................... B-1

Appendix C, Shoshone-Bannock Tribes' Comments ........................................................................ C-1

\section{FIGURES}

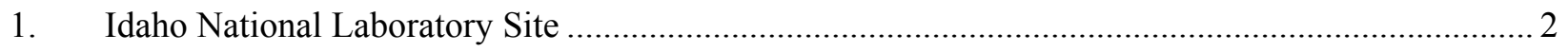

2. TAN-607, Technical Support Facility (looking northeast)........................................................ 4

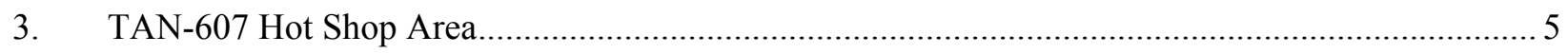



TABLES

1. Summary of radiological activity in TAN-607 (in curies) in 2006 and decayed to 2095 ................ 9

2. Summary of applicable or relevant and appropriate requirements for TAN-607 Hot Shop





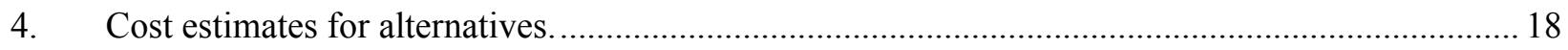




\section{ACRONYMS}

ACHP Advisory Council on Historic Preservation

$\mathrm{Ag} \quad$ silver

ARAR Applicable or Relevant and Appropriate Requirement

C carbon

CERCLA Comprehensive Environmental Response, Compensation, and Liability Act

CFR Code of Federal Regulations

$\mathrm{Ci} \quad$ curie

Co cobalt

Cs cesium

DEQ Department of Environmental Quality (Idaho)

DOE Department of Energy

DOE Idaho Department of Energy Idaho Operations Office

$\mathrm{dpm}$ disintegrations per minute

$\mathrm{EE} / \mathrm{CA} \quad$ engineering evaluation/cost analysis

EPA Environmental Protection Agency

$\mathrm{Eu} \quad$ europium

FFA/CO Federal Facility Agreement/Consent Order

g gram

$\mathrm{H} \quad$ hydrogen

HWMA Hazardous Waste Management Act

I iodine

ICDF Idaho CERCLA Disposal Facility

IDAPA Idaho Administrative Procedures Act

INL Idaho National Laboratory

$\mathrm{kg} \quad$ kilogram

L liter

m meter

MCL maximum contaminant level

mg milligram

MOA Memorandum of Agreement

NCP National Contingency Plan

$\mathrm{Np} \quad$ neptunium

OU operable unit 


\begin{tabular}{ll} 
PCB & polychlorinated biphenyl \\
pCi & picocurie \\
ppm & parts per million \\
RAO & remedial action objective \\
RCRA & Resource Conservation and Recovery Act \\
ROD & Record of Decision \\
Sb & antimony \\
SHPO & State Historic Preservation Officer (Idaho) \\
Sr & strontium \\
TAN & Test Area North \\
Tc & technetium \\
TSCA & Toxic Substances Control Act \\
TSF & Technical Support Facility \\
TU & temporary unit \\
U & uranium \\
USC & United States Code \\
VCO & Voluntary Consent Order \\
WAC & Waste Acceptance Criteria \\
WRRTF & Water Reactor Research Test Facility \\
yr & year \\
Zn & zinc \\
\hline
\end{tabular}




\section{Action Memorandum for Decommissioning of TAN-607 Hot Shop Area}

\section{PURPOSE}

This Action Memorandum documents selection of the proposed non-time critical removal action described herein for the Test Area North (TAN) 607 Hot Shop, Idaho National Laboratory, in Jefferson County Idaho. The proposed non-time-critical removal action was recommended in the TAN-607 Hot Shop Area Engineering Evaluation/Cost Analysis (ICP 2007). Development of this Action Memorandum has been performed in accordance with the Comprehensive Environmental Response, Compensation, and Liability Act (CERCLA) (42 USC $\S 9601$ et seq.), as amended by the "Superfund Amendments and Reauthorization Act of 1986 (SARA)" (Public Law 99-499), and in accordance with the "National Oil and Hazardous Substances Pollution Contingency Plan" (40 Code of Federal Regulations [CFR] 300). This removal action is consistent with the remedial action objectives of the Record of Decision (ROD) and supports the overall remediation goals at Waste Area Group 1.

\section{SITE CONDITIONS AND BACKGROUND}

This section provides summary background information, a description of INL and TAN-607 Hot Shop Area, and a discussion of previous cleanup actions in the area.

Despite significant efforts by the United States (U.S.) Department of Energy (DOE) to secure new business, no future mission has been identified for the TAN-607 Hot Shop Area. Its disposition has been agreed to by the Idaho State Historical Preservation Office documented in the Memorandum of Agreement signed October 2005 and it is therefore considered a surplus facility. A key element in DOE's strategy for surplus facilities is decommissioning to the maximum extent possible to ensure risk and building footprint reduction and thereby eliminating operations and maintenance cost. TAN-607 is designated as a historical Signature Property by DOE Headquarters Advisory Council on Historic Preservation and, as such, public participation was sought through the EE/CA process to determine the final disposition of the facility. The decommissioning action will place the TAN-607 Hot Shop Area in a final configuration that will be protective of human health and the environment. Decommissioning the TAN-607 Hot Shop Area is consistent with the joint DOE and U.S. Environmental Protection Agency (EPA) Policy on Decommissioning of Department of Energy Facilities Under the Comprehensive Environmental Response, Compensation and Liability Act, which establishes the CERCLA NTCRA process as the preferred approach for decommissioning surplus DOE facilities. Under this policy, a NTCRA may be taken when DOE determines that the action will prevent, minimize, stabilize, or eliminate a risk to human health and/or the environment. When DOE determines that a CERCLA NTCRA is necessary, DOE is authorized to evaluate, select, and implement the removal action that DOE determines is most appropriate to address the potential risk posed by the release or threat of release. This action is taken in accordance with applicable authorities and in conjunction with EPA and the State of Idaho pursuant to Section 5.3 of the Federal Facility Agreement and Consent Order. 


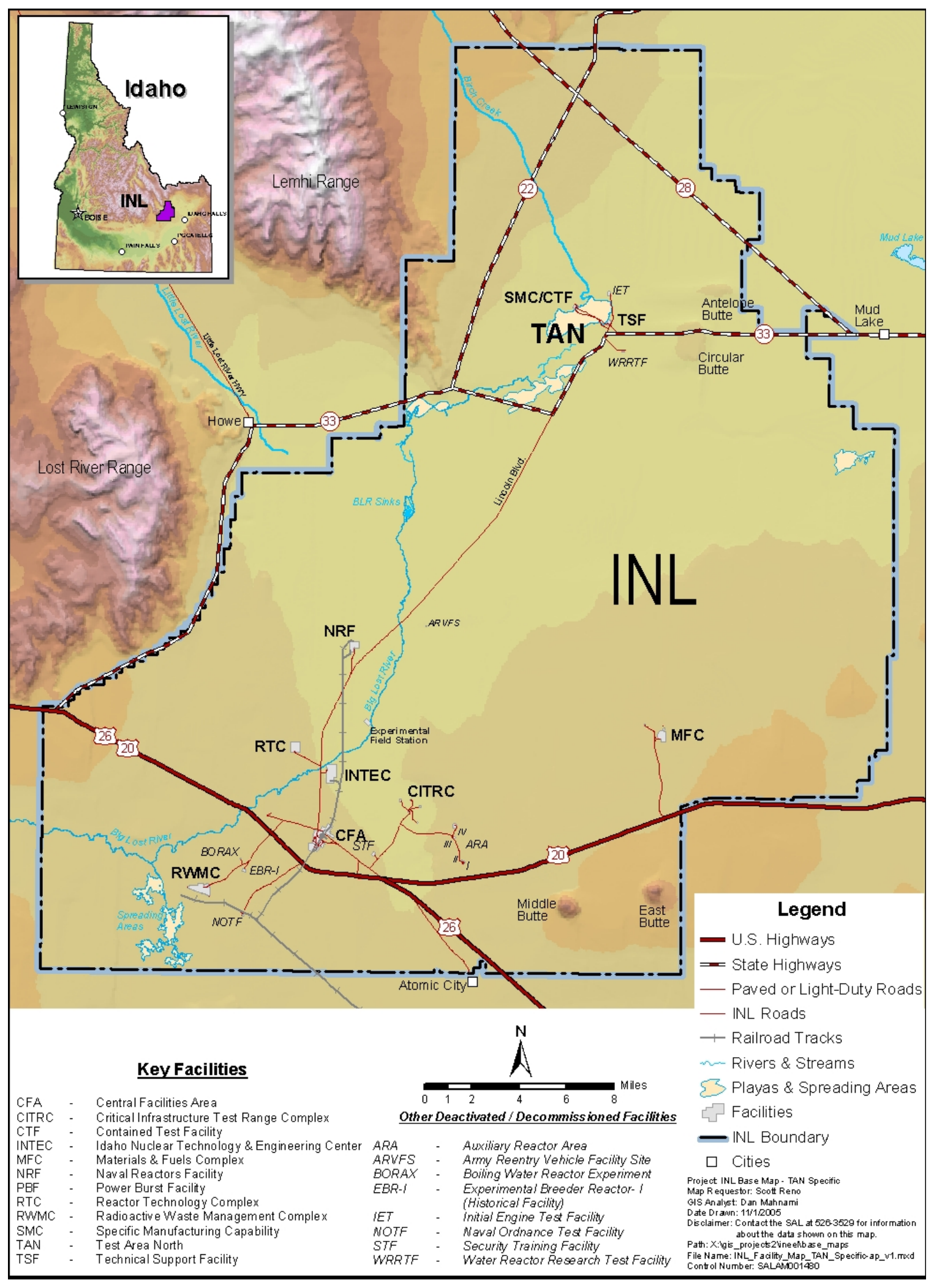

Figure 1. Idaho National Laboratory Site. 


\subsection{Site Description and Background}

\subsubsection{INL, Test Area North Area and TAN-607 Hot Shop Area}

The INL Site (Comprehensive Environmental Response, Compensation, and Liability Information System [CERCLIS] ID \#4890008952) is an 890- $\mathrm{mi}^{2}$ DOE facility located on the Snake River Plain in southeastern Idaho. DOE-ID controls the land within the INL Site. Public access is allowed on public highways, DOE-ID-sponsored tours, special-use permits, and the Experimental Breeder Reactor-I National Historic Landmark. DOE-ID also permits Shoshone-Bannock tribal members access to specific areas on the INL Site for cultural and religious purposes.

The INL consists of several facility areas situated on an expanse of otherwise undeveloped, cool-desert terrain. Buildings and structures at the INL are clustered within those facility areas, which are typically less than a square mile in size and separated from each other by miles of primarily undeveloped land. TAN is located at the north end of the INL about 27 miles northeast of the Central Facilities Area (CFA) (See Figure 1).

Population centers in the region include large towns in Idaho ( $>10,000$ residents) such as Idaho Falls, Pocatello, Rexburg, and Blackfoot, and several smaller towns $(<10,000)$ located around the INL such as Arco, Howe, Mud Lake, and Atomic City. These population centers are located within a 60 mile radius of TAN.

TAN is the most northerly group of facilities on the INL Site. The facilities were largely constructed between 1954 and 1961 to support the Aircraft Nuclear Propulsion Program (ANPP). Upon termination of this research, TAN structures were converted to support a variety of DOE-ID research projects. TAN encompassed several facilities including the TSF, the Initial Engine Test Facility (IETF), Lost-of-Fluid Test (LOFT) facility, Specific Manufacturing Capability (SMC) facility, and the Water Reactor Research Test Facility (WRRTF). The IETF, WRRTF, and LOFT have been demolished and completed to the final end states. SMC supports activities for the Department of the Army and is currently operational.

TAN-607, also known as the Technical Support Facility (TSF), was constructed between 1955 and 1957. TAN-607 is the original portion of the TSF and includes the hot shop/hot shop extension/Special Equipment Service (SES) room, storage pool and vestibule, hot cell, warm shop, and other support areas, including administrative, storage, and mechanical. The scope of the proposed removal action is to decommission the TAN-607 Hot Shop Area. The remainder of the TAN-607 facility (TAN-607A) is being decommissioned under a separate action. Limited deactivation and decontamination activities are currently being performed in TAN-607 Hot Shop Area. This includes asbestos abatement, decontamination of accessible above grade radioactively contaminated structures, and utility isolation. See Figure 2 for an exterior view of TAN-607. The plan view of the portion of TAN-607 that is being addressed under this Action Memorandum is shown in Figure 3 as the unshaded area.

The hot shop was originally constructed in 1955 in support of the Aircraft Nuclear Propulsion Program and was later used to support both government nuclear operations and commercial fuel assembly evaluations. The hot shop is a 50- $\times 165-\mathrm{ft}$ concrete-shielded high bay with a 55-ft ceiling. Large overhead manipulators, three wall-mounted manipulators, and remote handling equipment are located in the bay for radioactive materials operations. The hot shop walls and ceiling are constructed of reinforced concrete. Shielded operating galleries are located at two elevations outside the north and south walls of the hot shop and include viewing windows for remote operations. Access to the storage pool and the hot 


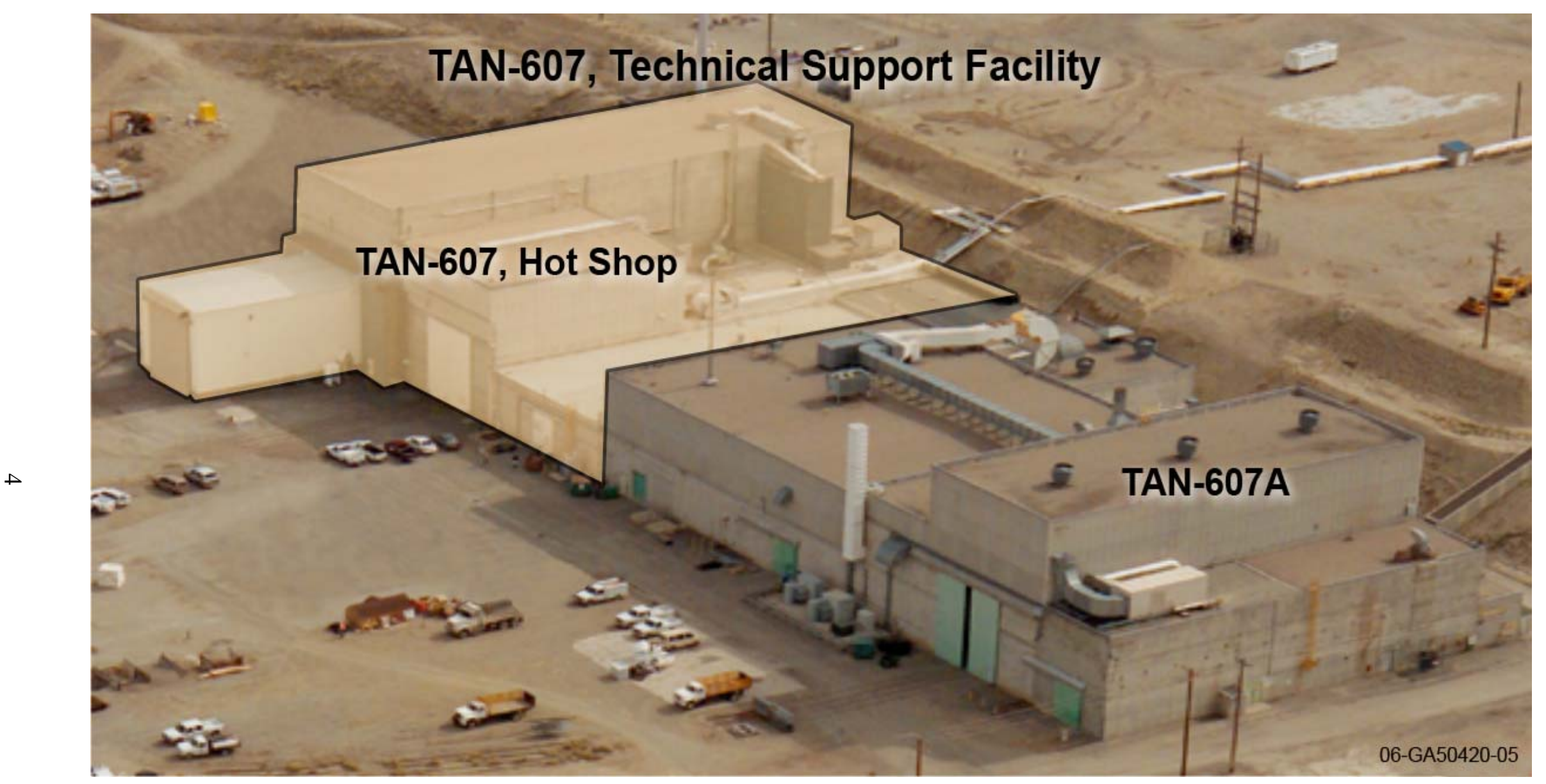

Figure 2. TAN-607, Technical Support Facility (looking northeast). 


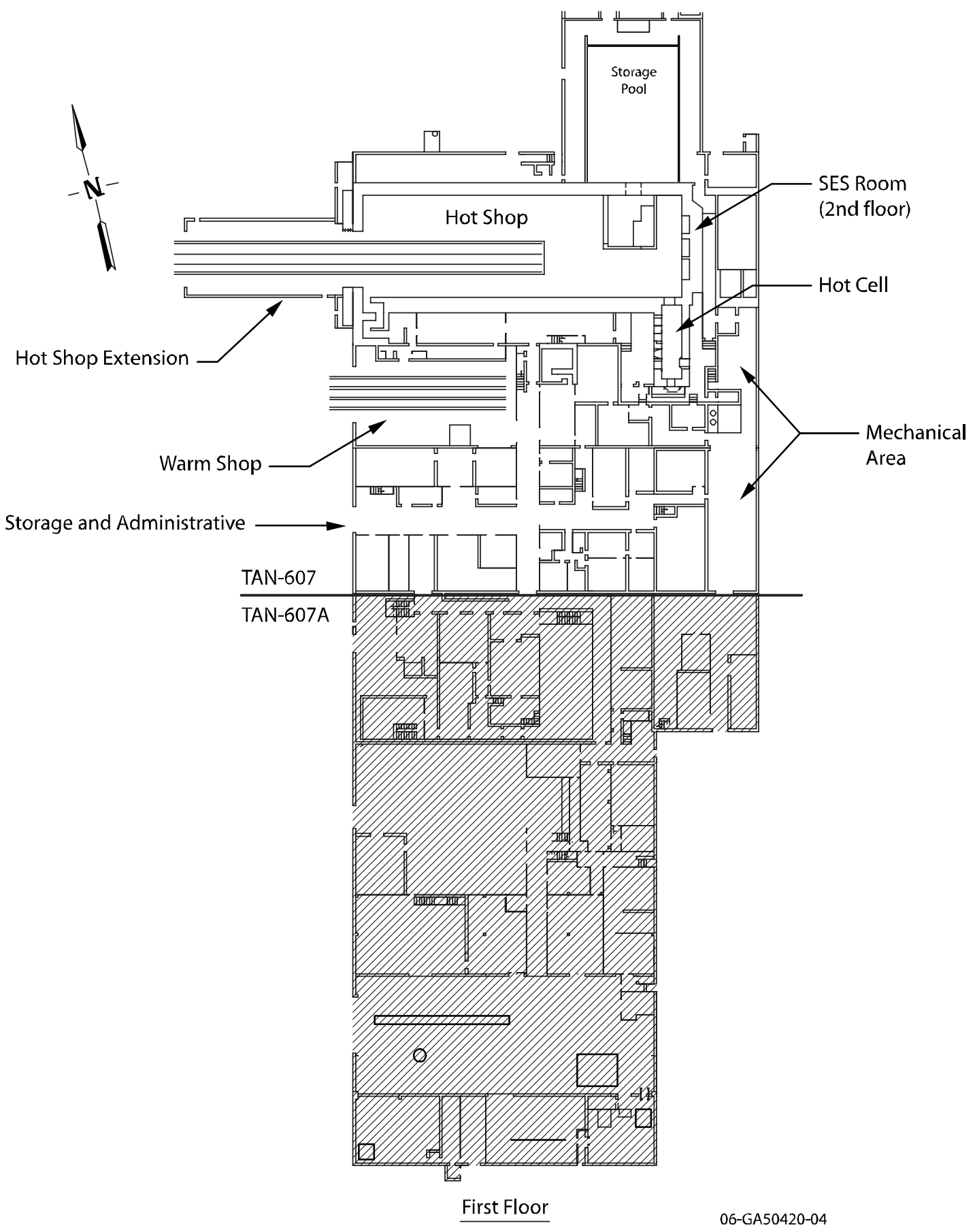

Figure 3. TAN-607 Hot Shop Area. 
cell is available from the hot shop. The west wall, adjacent to the hot shop extension, has a 28 -ft-high $\times$ 33-ft-wide door that was used as a truck and locomotive entrance. The hot shop extension provided a waiting area for trucks and components entering the hot shop and was also used for temporary storage of waste and other materials. The SES room is an extension of the hot shop on the east side. The SES room floor level is $13 \mathrm{ft}$ above the hot shop floor level and was used for shielded maintenance of the overhead crane and manipulators.

The 24-ft-deep storage pool was used for underwater storage of fissile and radioactive materials. A passageway under the north hot shop wall connects the storage pool to the storage pool vestibule that is located in the hot shop. All spent nuclear fuel items that were stored in the storage pool have been removed. The water has been removed and the walls and floors of the storage pool and vestibule have been cleaned and sealed to control the spread of radiological contamination.

The hot cell, formerly known as the Radioactive Materials Laboratory, is located adjacent to the southeast corner of the hot shop. The hot cell is a typical hot cell that was used for conventional remote physical and chemical inspections and tests. The hot cell was also used for small-scale assembly and disassembly operations (e.g., disassembly and assembly of fuel rods). The hot cell is a $10-\times 35-\times 20$-ft-high cell constructed with 4 -ft-thick high-density concrete walls. The walls and floors are lined with a 1/4-in.-thick stainless-steel liner. Hot cell viewing windows are filled with mineral oil.

The warm shop was originally used as an assembly area for nonradioactive components and complete nuclear systems and functioned as a cold assembly area. When the TAN-607A High Bay Area became operational, the warm shop was then used for assembly and maintenance of low-activity radioactive components as well as for receiving and staging of contained hot assemblies and components waiting for processing in the hot shop, hot cell, or hot cell annex. The welding shop and carpentry shop are both currently located in the warm shop.

Other support areas included administrative offices, storage, and mechanical areas. An example of the latter is the equipment room that housed the demineralized water system tanks, air cleaning tanks, and tanks associated with the boiler system.

\subsection{Previous Closure/Cleanup Activities at TAN}

Recent CERCLA activities at TAN have been focused predominantly at the TSF area, which is where TAN-607 is located. In addition, over the last 2 years, 32 buildings and structures have been decommissioned at the TSF and at the Loss-of-Fluid Test Facility, along with the completion of several HWMA/RCRA closure activities.

\subsubsection{CERCLA Activities}

CERCLA cleanup actions have occurred or will occur in accordance with the Record of Decision Amendment for the V-Tanks (TSF-09 and TSF-18) and Explanation of Significant Differences for the PM-2A Tanks (TSF-26) and TSF-06, Area 10, at Test Area North, Operable Unit 1-10 (DOE-ID 2004a). These CERCLA actions are addressed as follows:

- V-Tanks (TSF-09 and TSF-18) - This action will be completed in 2007

- PM-2A Tanks (TSF-26) - This action was completed during the summer of 2005

- Soil Contamination Area South of the Turntable (TSF-06, Area B) - This action was completed during the summer of 2004 
- Disposal Pond (TSF-07) - This action will be complete subsequent to TAN-607 demolition

- Burn Pits (TSF-03 and WRRTF-01) - This action was completed during the summer and fall of 2004

- Fuel Leak (WRRTF-13) - This action was completed during the summer of 2004.

As noted above, some CERCLA actions have been completed (e.g., the PM-2A Tanks, Burn Pits) while others are still ongoing. The V-Tanks are currently undergoing remediation. For two sites, the TSF Injection Well (TSF-05) and the Contaminated Ground Water Beneath TSF (TSF-23), the CERCLA remedial action is being implemented under the Operable Unit (OU) 1-07B Work Plan (DOE-ID 2004b).

Two non-time-critical removal actions are being conducted at TAN at this time. TAN-607A is addressed in Engineering Evaluation/Cost Analysis (EE/CA) Decommissioning of TAN-607A (ICP 2006), and other buildings and structures not part of TAN-607 are included in Engineering Evaluation/Cost Analysis (EE/CA) for General Decommissioning Activities under the Idaho Cleanup Project (DOE-ID 2006b). If any newly identified release sites are discovered, the Department of Energy Idaho Operations Office (DOE Idaho) will consult with the Idaho Department of Environmental Quality (DEQ) and EPA regarding remediation under this Action Memorandum; or, if the extent of contamination is beyond the footprint to be addressed under this Action Memorandum, the sites will be addressed under the Federal Facility Agreement/Consent Order (FFA/CO) (DOE-ID 1991) or other regulatory programs.

\subsubsection{Voluntary Consent Order HWMA/RCRA Closure Activities}

Voluntary Consent Order (VCO) actions are being implemented to ensure compliance with Hazardous Waste Management Act (HWMA)/Resource Conservation and Recovery Act (RCRA) regulations. The VCO is a consent order between DOE Idaho and DEQ to address potential HWMA/RCRA waste issues. All VCO actions at TAN-607 have been completed except the characterization and removal of any solid materials determined to be hazardous waste in the lines and trenches in the Hot Shop Area. The VCO actions are outside of the scope of this Action Memorandum.

\subsection{Current Closure/Cleanup Activities at TAN-607 Hot Shop Area}

Currently, deactivation actions are being performed. The actions include asbestos abatement, utility isolation, decontamination, removing the radiologically contaminated ventilation system, and sampling and removing the radiologically contaminated filter banks. All potential HWMA/RCRA and Toxic Substances Control Act (TSCA) materials are also being removed. This includes, but is not limited to, lead, circuit boards, mercury switches, ballasts, and fluorescent tubes. These materials will be characterized and dispositioned per appropriate regulatory requirements as they are removed. In the decontamination room, the high-efficiency particulate air filters were removed from the banks and managed appropriately. 


\section{THREAT TO PUBLIC HEALTH, WELFARE, AND/OR THE ENVIRONMENT}

This section discusses potential threats to Public Health, welfare and/or the environment from the remaining contaminant inventories at the Hot Shop.

\subsection{Threats to Public Health, Welfare and/or the Environment}

Conditions at this site meet the criteria for a non-time-critical removal action as stated in the National Contingency Plan (NCP), 40 CFR 300.415, as follows:

Actual or potential exposure to hazardous substances or pollutants or contaminants by nearby populations or the food chain $(300.415(b)(2)(i))$. While access to the INL is restricted, there is the potential that over time the structure will decay and the radionuclides could be released into the environment. This would create the potential for exposure to concentrations of radionuclides via inhalation of wind blown dust from the debris or direct ingestion of contaminated soils, by nearby populations and INL workers. The location of the Hot Shop is approximately 5 miles from the boundary of INL. The land use of the property outside of the fence line is agriculture, including grazing, hay and potato production and other agricultural products. The Ecological Based Screening Levels (EBSL) are established to evaluate whether there could be an internal exposure increase to biota (plants and animals) that would result in the lack of maintenance or recovery of healthy local populations of ecological receptors that are, or should be, at or near the site. If no action is taken, $\mathrm{Pu}-239$ would exceed the maximum concentration screening value.

Actual or potential contamination of a drinking water supply or sensitive ecosystem (300.415(b)(2)(ii)). If no action is taken there exists a potential for the contaminants to migrate to the Snake River Plain Aquifer and result in exceedances of the MCLs. GWSCREEN modeling performed for the $\mathrm{EE} / \mathrm{CA}$ indicated a potential threat to groundwater of greater than 1 in 10,000 (EDF-7515).

High levels of hazardous substances or pollutants in soils largely at or near the surface that may migrate (300.415(b)(2)(iv)). The total activity from radionuclides at this site is identified in Table 1. If no action is taken, there exist the potential for this contamination to be ingested or transported via the wind to receptors.

\subsection{Remaining Radionuclide Inventory}

To determine the radiological content for TAN-607, a number of methods were employed, including extensive scans and wipes of building surfaces, dose rate surveys, in situ gamma spectroscopy, and/or sampling and laboratory analysis for the various isotopes and radiations potentially present (gamma, alpha, pure beta-emitters). Where available, existing characterization information from historical documents and Engineering Design Files was used. Numerous samples have been taken over the life of the facility, and waste streams for TAN-607 consistently contain primarily reactor-produced isotopes Cs-137, Sr-90, and Co-60. This holds true for the hot shop, hot cell, empty storage pool and vestibule, and hot cell drains for which these three isotopes account for the vast majority, over $90 \%$, of activity present. Alpha-emitters typically account for less than 1\% of total activity in the TAN-607 Hot Shop Area. Table 1 summarizes the radiological activity in TAN-607 in 2006 and its decay calculations in 2095. 
Table 1. Summary of radiological activity in TAN-607 (in curies) in 2006 and decayed to 2095.

\begin{tabular}{|c|c|c|c|c|c|c|}
\hline Radionuclide & $\begin{array}{c}\text { Hot Shop } \\
\text { and Tunnel }\end{array}$ & Storage Pool & TAN Hot Cell & $\begin{array}{c}\text { Hot Shop } \\
\text { Sumps/Drains }\end{array}$ & $\begin{array}{c}\text { Total } \\
\text { 2006 Curies }\end{array}$ & $\begin{array}{c}\text { Total } \\
2095 \text { Curies }\end{array}$ \\
\hline Ag-108m & $-^{\mathrm{a}}$ & - & - & $5.58 \mathrm{E}-04$ & $5.58 \mathrm{E}-04$ & $3.43 \mathrm{E}-04$ \\
\hline Am-241 & $5.99 \mathrm{E}-02$ & 7.92E-02 & $9.50 \mathrm{E}-03$ & $4.48 \mathrm{E}-01$ & $5.97 \mathrm{E}-01$ & $6.83 \mathrm{E}-01$ \\
\hline $\mathrm{C}-14$ & - & - & - & $2.74 \mathrm{E}-04$ & $2.74 \mathrm{E}-04$ & $2.71 \mathrm{E}-04$ \\
\hline $\mathrm{Cm}-242$ & - & - & $4.28 \mathrm{E}-07$ & - & $4.28 \mathrm{E}-07$ & $4.68 \mathrm{E}-67$ \\
\hline $\mathrm{Cm}-244$ & - & - & $1.35 \mathrm{E}-03$ & - & $1.35 \mathrm{E}-03$ & $4.48 \mathrm{E}-05$ \\
\hline Co-60 & 5.30E-01 & 7.01E-01 & $7.76 \mathrm{E}-04$ & $1.05 \mathrm{E}-01$ & $1.34 \mathrm{E}+00$ & $1.11 \mathrm{E}-05$ \\
\hline Cs-137 & $6.17 \mathrm{E}+00$ & $8.18 \mathrm{E}+00$ & $1.15 \mathrm{E}-01$ & $1.56 \mathrm{E}+01$ & $3.01 \mathrm{E}+01$ & $3.90 \mathrm{E}+00$ \\
\hline Eu-152 & - & - & $1.43 \mathrm{E}-03$ & - & $1.43 \mathrm{E}-03$ & $1.53 \mathrm{E}-05$ \\
\hline Eu-154 & - & - & $2.47 \mathrm{E}-03$ & - & $2.47 \mathrm{E}-03$ & $2.23 \mathrm{E}-05$ \\
\hline $\mathrm{Eu}-155$ & - & - & $4.60 \mathrm{E}-04$ & - & $4.60 \mathrm{E}-04$ & $1.82 \mathrm{E}-09$ \\
\hline $\mathrm{H}-3$ & $2.81 \mathrm{E}-02$ & $3.72 \mathrm{E}-02$ & - & $6.24 \mathrm{E}-02$ & $1.28 \mathrm{E}-01$ & $8.42 \mathrm{E}-04$ \\
\hline $\mathrm{I}-129^{\mathrm{b}}$ & - & $1.38 \mathrm{E}-04$ & - & - & $1.38 \mathrm{E}-04$ & $1.38 \mathrm{E}-04$ \\
\hline Ni-63 & 1.39E-01 & $1.84 \mathrm{E}-01$ & - & 4.19E-01 & 7.42E-01 & $4.01 \mathrm{E}-01$ \\
\hline Np-237 & - & - & $2.18 \mathrm{E}-06$ & - & $2.18 \mathrm{E}-06$ & $2.22 \mathrm{E}-05$ \\
\hline $\mathrm{Pu}-238$ & $1.14 \mathrm{E}-02$ & $1.51 \mathrm{E}-02$ & $6.92 \mathrm{E}-03$ & 4.37E-02 & $7.71 \mathrm{E}-02$ & $3.82 \mathrm{E}-02$ \\
\hline $\mathrm{Pu}-239$ & 4.49E-02 & $5.94 \mathrm{E}-02$ & 4.87E-03 & 4.22E-01 & 5.31E-01 & 5.30E-01 \\
\hline $\mathrm{Pu}-240$ & 4.49E-02 & $5.94 \mathrm{E}-02$ & - & - & $1.04 \mathrm{E}-01$ & $1.03 \mathrm{E}-01$ \\
\hline $\mathrm{Pu}-241$ & $7.78 \mathrm{E}-01$ & $1.03 \mathrm{E}+00$ & $1.23 \mathrm{E}-01$ & $3.71 \mathrm{E}+00$ & $5.64 \mathrm{E}+00$ & $7.78 \mathrm{E}-02$ \\
\hline Sr-90 & $5.48 \mathrm{E}+00$ & $7.26 \mathrm{E}+00$ & $1.77 \mathrm{E}-01$ & $2.48 \mathrm{E}+01$ & $3.77 \mathrm{E}+01$ & $4.36 \mathrm{E}+00$ \\
\hline Tc-99 & - & - & $3.60 \mathrm{E}-05$ & - & $3.60 \mathrm{E}-05$ & $3.60 \mathrm{E}-05$ \\
\hline U-233 & $1.99 \mathrm{E}-03$ & $2.63 \mathrm{E}-03$ & - & $2.05 \mathrm{E}-03$ & $6.67 \mathrm{E}-03$ & $6.67 \mathrm{E}-03$ \\
\hline U-234 & $1.99 \mathrm{E}-03$ & $2.63 \mathrm{E}-03$ & $1.25 \mathrm{E}-04$ & $2.05 \mathrm{E}-03$ & $6.80 \mathrm{E}-03$ & $6.81 \mathrm{E}-03$ \\
\hline U-235 & $1.32 \mathrm{E}-04$ & $1.75 \mathrm{E}-04$ & $6.70 \mathrm{E}-06$ & $5.23 \mathrm{E}-04$ & 8.37E-04 & 8.37E-04 \\
\hline U-238 & $3.30 \mathrm{E}-04$ & $4.38 \mathrm{E}-04$ & 7.11E-06 & $9.24 \mathrm{E}-04$ & $1.70 \mathrm{E}-03$ & $1.70 \mathrm{E}-03$ \\
\hline Total & $1.33 \mathrm{E}+01$ & $1.76 \mathrm{E}+01$ & 4.43E-01 & $4.56 \mathrm{E}+01$ & $7.70 \mathrm{E}+01$ & $1.03 \mathrm{E}+01$ \\
\hline \multicolumn{7}{|c|}{$\begin{array}{l}\text { Notes: } \\
\text { Cs-137 and Sr-90 daughters Ba-137m and Y-90 not reported. } \\
2006 \text { isotopes decayed to } 2095 \text { in Microshield v. } 6.20 \text { licensed to INL. (Areva 2004) }\end{array}$} \\
\hline \multicolumn{7}{|c|}{$\begin{array}{l}\text { The letter "E" is referring to scientific notation when displaying figures (i.e. } 5.99 E-02=0.0599 \text { curies), this is the standard } \\
\text { method of displaying a number to the }+/ \text { - power of } 10 \text {. }\end{array}$} \\
\hline \multicolumn{7}{|c|}{$\begin{array}{l}\text { a. }-=\text { not detected. } \\
\text { b. I-129 is scaled in at abundance as identified in previous characterization efforts. }\end{array}$} \\
\hline
\end{tabular}




\subsection{Remaining Nonradionuclide Inventory}

Extensive nonradiological characterization has been completed in the TAN-607 Hot Shop Area. As discussed above, potential HWMA/RCRA issues have been or are being addressed under the terms of the VCO. The removal of contaminants such as asbestos and PCBs represent the first steps in eliminating the threat that this structure poses to human health and the environment. All remaining nonradiological contamination is expected to be removed as part of the deactivation activities. Therefore the nonradiological contaminants that are currently being removed within this structure are not being directly addressed in this Action Memorandum.

\section{ENDANGERMENT DETERMINATION}

Actual or potential releases of radiological and hazardous substances from this site, if not addressed by implementing the removal action selected in the Action Memorandum, may present an imminent and substantial endangerment to public health, or welfare, or the environment. As the Hot Shop Area buildings and structures continue to age, the threat increases with time, and containing these materials and preventing them from being released to the environment becomes more difficult. The surveillance and maintenance (S\&M) activities required to confine the hazardous substances may increase the risk of potential exposure to personnel.

The potential exposure to workers and wildlife, the potential threat of future releases, and the substantial risks associated with the radiological and hazardous substances at the facilities addressed by this Action Memorandum justify use of CERCLA removal action authority in accordance with Section 300.415(b)(2) of the "National Oil and Hazardous Substances Pollution Contingency Plan." Actual and/or threatened releases of hazardous substances from these facilities have the potential to present a threat to public health and/or the environment.

This section provides information regarding the proposed action, how this action contributes to remedial performance at TAN and the basis for selection of the proposed alternative.

\subsection{Proposed Action}

Two alternatives and a No Action alternative were evaluated for the TAN-607 Hot Shop. These alternatives are described in detail in section 4.2. The removal of the TAN-607 Hot Shop is the consistent feature of Alternatives 2 and 3. Alternative 2 would leave the Hot Shop in a "cold, dark and dry" condition until DOE no longer managed the site, projected to be in 2095. The No Action Alternative represents a theoretical scenario where the building is allowed to weather and degrade, releasing the radionuclides and other contaminants, such as asbestos and PCBs, into the environment.

The selected alternative (Alternative 3) is to demolish the building beginning this year. The action consists of removing TAN-607 Hot Shop Area aboveground structures and components, removing belowground components, removing structural walls to $3 \mathrm{ft}$ below grade, removing residual radiological and any potential nonradiological contamination in the soil, and filling the void to grade with clean solid inert material. The specific components of the selected alternative as follows:

- Demolishing the aboveground structures and components, and removing the radiologically contaminated debris.

- Radiologically contaminated debris that does meet the RAOs will be left in the excavation created from demolition of TAN-607 and the adjacent void remaining after completion of the V-Tanks soil removal project. 
- Radiologically contaminated debris that does not meet the RAOs will be disposed of in the ICDF subject to meeting the WAC.

- Nonradiologically contaminated and nonhazardous waste will be disposed of at the TAN Demolition Landfill subject to meeting the WAC. If waste does not meet the TAN Demolition Landfill or ICDF WAC, a suitable off-Site disposal location will be determined (e.g., EnergySolutions).

- Upon completion of demolition, the remaining void will be backfilled with solid inert material, graded to meet the natural contour of the area and reseeded.

\subsection{Contribution of Remedial Performance at TAN}

The removal action objective for this non-time-critical removal action is as follows: Reduce risk from external radiation exposure to a total excess cancer risk of less than 1 in 10,000 for a hypothetical resident at 2095 and the current and future worker. Per OU 1-10 ROD Amendment (DOE-ID 2004a), the TAN area is expected to be under the control of the government until 2095 (DOE-ID 2004a). In addition, general CERCLA protectiveness standards at INL Site seek to prevent future releases to the Snake River Plain Aquifer that would result in migration of contaminants to the aquifer such that drinking water MCLs may be exceeded and to ensure cumulative excess cancer risks from multiple contaminants of concern remain less than 1 in 10,000 for a hypothetical resident at 2095.

No future removal actions are currently anticipated at TAN. The removal action objective is consistent with the remedial action objectives of the ROD and will be consistent with any future actions. The removal action is also consistent with future RCRA actions at TAN to the extent practicable. The removal action objective is predicated on the current and future land uses established for the TAN area in the ROD, which includes industrial land use until at least 2095 and possible unrestricted land use thereafter. If any newly identified release sites are discovered during implementation of the selected alternative, DOE Idaho will consult with DEQ and EPA regarding potential inclusion of the newly identified release site for evaluation under the FFA/CO or whether to address the newly identified release site under other regulatory programs.

\subsection{Proposed Alternatives and Basis for Selection of the Proposed Alternative}

The EE/CA is contained in the Administrative Record. The EE/CA evaluated three alternatives as described below. The basis for selection of the proposed alternative is addressed in Section 4.3.4.

\subsubsection{Alternative 1 - No Action Alternative}

The No Action alternative is a hypothetical and conservative "baseline" established for comparison reasons. The primary assumption is that the sum of identified radiological contamination, if not properly contained or controlled, may be released to the environment causing a potential risk to receptors (current and future workers, hypothetical future residents, and the environment). This assumption is for comparative purposes only and does not reflect the DOE mandate to monitor, maintain, and mitigate potential or actual release from any facility or site to ensure protection to the public and the environment. 


\subsubsection{Alternative 2 - Cold, Dark, and Dry with Continued Surveillance and Monitoring}

Under Alternative 2, the facility will be placed in a cold, dark, and dry condition. Utilities will be disconnected and remaining liquids will be removed prior to placing the building into long-term surveillance and monitoring. Long-term surveillance and monitoring would continue until the building is finally decommissioned in 2095. At the end of the DOE institutional control period, the TAN-607 Hot Shop Area will be decommissioned. The year 2095 is used as the basis for the period of continued surveillance and monitoring as that timeframe is established in the OU 1-10 ROD for TAN (DOEID 1999). The OU 1-10 ROD includes industrial land use until at least 2095 and the potential for unrestricted land use thereafter. Implementation of Alternative 2 will delay the start of decommissioning and will require expenditures for continued surveillance and monitoring until final decommissioning. The cost analysis, which is addressed in Section 6.0 of this Action Memorandum, evaluates the period of surveillance and monitoring through 2095 and the final demolition of TAN-607 in 2095 (in 2006 dollars).

\subsubsection{Alternative 3-Demolition, Removal, and Disposal of Building and Building Contents to Meet the Remedial Action Objectives}

The scope of Alternative 3 (selected alternative) includes any deactivation or decontamination activities not performed under the Engineering Evaluation/Cost Analysis (EE/CA) for General Decommissioning Activities under the Idaho Cleanup Project (DOE-ID 2006b). Alternative 3 consists of demolishing the TAN-607 aboveground structures and components, removing belowground noninert components, and removing the radiologically contaminated portions of the hot shop, hot cell, and the empty storage pool and vestibule that do not meet the RAOs (shown in blue in Figure 4). Radiologically contaminated debris that meet the RAOs, as defined in the Record of Decision Amendment for the V-Tanks (TSF-09 and TSF-18) and Explanation of Significant Differences for the PM-2A Tanks (TSF-26) and TSF-06, Area 10, at Test Area North, Operable Unit 1-10 (DOE-ID 2004), will be left in the excavation created from demolition of TAN-607 and the adjacent void remaining after completion of the V-Tanks soil removal project (shown in red in Figure 4). If radiologically contaminated debris does not meet the RAOs, it will be disposed of in the ICDF subject to meeting the WAC. Nonradiologically contaminated and nonhazardous waste will be disposed of at the TAN Demolition Landfill subject to meeting the WAC.

\subsubsection{Basis for Selection of the Proposed Alternative}

Removal of the building is necessary to remove the radionuclides present and to be consistent with DOE's strategy for the management of surplus buildings. A key element in DOE's strategy for surplus facilities is decommissioning to the maximum extent possible to prevent unacceptable risk and for building footprint reduction and thereby eliminating operations and maintenance cost.

Alternative 3 best meets the criteria for assessing the effectiveness of the various alternatives. Alternatives 2 and 3 meet ARARs and are effective in protecting human health and the environment. Alternative 3 best meets these criteria by removing the contamination this year and not waiting till 2095 when DOE will no longer manage the site. By acting now, risk to workers is decreased since there will be no need for periodic inspections and the structure of the building will not be degraded over time. Also, there will be a cost savings by not having to perform the periodic surveillance and maintenance through the 2095 Institutional Control period. In addition, current profiles include sufficient funding to complete the removal actions now. There is no certainty that funding would exist for this action at 2095 so it is prudent to implement this removal action at this time. In addition, current waste projections for this removal action can be disposed within the boundaries of the INL provided the waste meets the waste acceptance criteria (WAC) of the receiving facility. Should the waste not meet the WAC it will be shipped to an appropriate facility off of INL in compliance with the off-site policy. 

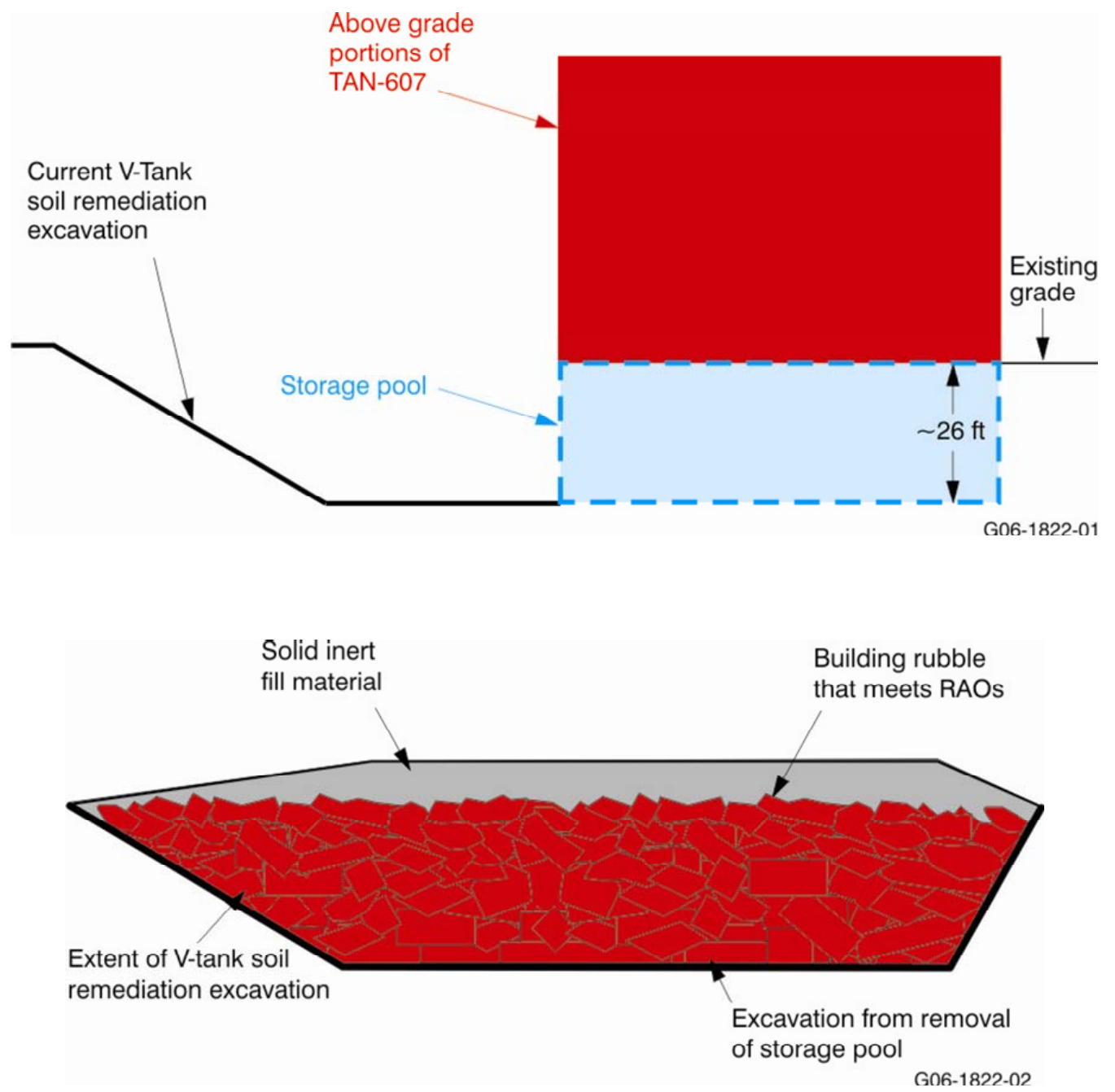

Figure 4. End state of TAN-607

\subsection{Compliance with Environmental Regulations, Including Those That Are Applicable, or Relevant and Appropriate Requirements}

\subsubsection{CERCLA}

Section 121 of CERCLA (42 USC $\S 9621$ ) requires the responsible CERCLA implementing agency to ensure that the substantive standards of HWMA/RCRA and other applicable laws will be incorporated into the federal agency's design and operation of its long-term remedial actions and into its more immediate removal actions. DOE Idaho is the implementing agency for this non-time-critical removal action. EPA and DEQ have reviewed the engineering evaluation/cost analysis (EE/CA) and concur with this Action Memorandum.

Implementation of Alternative 3 will result in the generation and subsequent management of radioactive and nonradioactive wastes. Table 2 lists the applicable or relevant and appropriate 
requirements (ARARs) that have been identified for this alternative. These ARARs are a compilation and expansion of the ARARs identified in the OU 1-10 ROD Amendment (DOE-ID 2004a). The ARARs list is based on several key assumptions:

- Waste managed under CERCLA will most likely be disposed of at the ICDF landfill and the TAN demolition landfill, subject to meeting the WAC.

- If decontamination liquids are generated, they will be disposed of at the ICDF evaporation ponds subject to meeting the WAC.

- Debris generated during demolition of TAN-607 Hot Shop Area may have paint that has polychlorinated/biphenyls (PCBs). If encountered, such wastes may trigger substantive requirements of the TSCA. Lead-contaminated paint may be generated during demolition, which will be subject to the substantive requirements of RCRA hazardous waste regulations. These wastes are planned for disposal at either the ICDF landfill or TAN demolition landfill if they are found to be eligible for disposal as solid waste.

- Asbestos-containing material will be encountered incidental to performance of the non-time-critical removal action. This waste will be subject to specific asbestos regulations and will be acceptable for disposal at the ICDF and/or, if not radiologically contaminated, at the TAN demolition landfill. Friable asbestos will be removed and disposed of as required by the National Emission Standards for Hazardous Air Pollutants.

\subsubsection{Cultural Resources}

Section 106 of the National Historic Preservation Act of 1966, as amended, requires agencies to consider the impact of undertakings on properties listed or eligible for listing in the National Register of Historic Places and to consult with the Idaho State Historic Preservation Officer (SHPO) and other interested parties when impacts are likely (16 USC $\S 470$ et seq.). It also requires federal agencies to invite the Advisory Council on Historic Preservation (ACHP) to participate in consultation when impacts may be adverse. The Section 106 process has been tailored to meet the unique needs of the INL Site and is described in the INL Cultural Resources Management Plan (DOE-ID 2005).

TAN-607 proper (TAN-607 Hot Shop Area and TAN-607A) is a historic property eligible for nomination to the National Register of Historic Places. TAN-607 proper has been designated a Signature Property by DOE Headquarters. DOE Idaho has decided to proceed with demolition of TAN 607. As a Signature Property, public review of the disposition of the facility is required. To mitigate the adverse impacts caused by such action, DOE Idaho, through formal consultation with the Idaho SHPO, has developed a Memorandum of Agreement (MOA) that outlines measures to preserve the TAN-607 proper history, as well as commitments to edit and republish a public history book on the INL, publish and distribute historical reports that are written for inclusion in the Library of Congress collections, endow a university scholarship for students pursuing a degree in a preservation-related discipline, and preserve technical reports, engineering drawings, historic photographs, and other important documents in an INL archive via the support of a professional archivist. DOE Idaho invited ACHP to participate in consultation and to be a signature to the MOA. However, the ACHP declined to participate. The MOA was signed by DOE Idaho and the Idaho SHPO in October 2005 and outlines a schedule for completing each stipulated mitigation measure. (DOE and SHPO 2005) 
Table 2. Summary of applicable or relevant and appropriate requirements for TAN-607 Hot Shop Area non-time-critical removal action.

\begin{tabular}{|c|c|c|}
\hline Requirement (Citation) & $\begin{array}{c}\text { ARAR } \\
\text { Type }\end{array}$ & Comments \\
\hline \multicolumn{3}{|l|}{ Clean Air Act and Idaho Air Regulations } \\
\hline “Toxic Substances,” IDAPA 58.01.01.161 & A & $\begin{array}{l}\text { Applies to any toxic substances emitting during implementation of the } \\
\text { removal action. }\end{array}$ \\
\hline $\begin{array}{l}\text { "National Emission Standards for Hazardous Air } \\
\text { Pollutants" } \\
<10 \text { mrem/yr, } 40 \text { CFR } 61.92 \text {, "Standard" }\end{array}$ & A & Applies to building demolition and the waste-handling activities. \\
\hline $\begin{array}{l}\text { "National Emission Standards for Hazardous Air } \\
\text { Pollutants" } \\
\text { "Emission Monitoring and Test Procedures," } 40 \text { CFR } 61.93\end{array}$ & A & Applies to building demolition and the waste-handling activities. \\
\hline $\begin{array}{l}\text { "National Emission Standards for Hazardous Air } \\
\text { Pollutants" } \\
\text { "Compliance and Reporting," } 40 \text { CFR 61.94(a) }\end{array}$ & A & Applies to building demolition and the waste-handling activities. \\
\hline $\begin{array}{l}\text { "National Emission Standards for Hazardous Air } \\
\text { Pollutants" } \\
\text { "Standards for Demolition and Renovation," } \\
40 \text { CFR } 61.145\end{array}$ & A & $\begin{array}{l}\text { Applies to any asbestos-containing materials removed during the } \\
\text { decommissioning. }\end{array}$ \\
\hline $\begin{array}{l}\text { "Rules for Control of Fugitive Dust," and "General Rules," } \\
\text { IDAPA 58.01.01.650 and .651 }\end{array}$ & A & Applies to building demolition and the waste-handling activities. \\
\hline \multicolumn{3}{|l|}{ RCRA and Idaho Hazardous Waste Management Act } \\
\hline \multicolumn{3}{|c|}{ "Standards Applicable to Generators of Hazardous Waste," IDAPA 58.01.05.006, and the following, as cited in it: } \\
\hline "Hazardous Waste Determination," 40 CFR 262.11 & A & Applies to waste that would be generated during the removal action. \\
\hline \multicolumn{3}{|l|}{ General Facility Standards } \\
\hline \multicolumn{3}{|c|}{ IDAPA 58.01.05.008, "Standards for Owners and Operators of Hazardous Waste Treatment, Storage, and Disposal Facilities," and the following, as cited in it } \\
\hline "Temporary Units (TU)," 40 CFR 264.553 & A & $\begin{array}{l}\text { Waste may be treated or temporarily stored in a temporary unit prior to } \\
\text { disposal. }\end{array}$ \\
\hline "Staging Piles," 40 CFR 264.554 & A & Waste may be temporarily staged prior to disposal. \\
\hline
\end{tabular}


Table 2. (continued).

\begin{tabular}{|c|c|c|}
\hline Requirement (Citation) & $\begin{array}{l}\text { ARAR } \\
\text { Type }\end{array}$ & Comments \\
\hline "General Inspections Requirements," 40 CFR 264.15 & A & $\begin{array}{l}\text { Applies to a facility staging, storing, or treating hazardous waste prior to } \\
\text { transfer to the ICDF or an off-Site facility. }\end{array}$ \\
\hline "Preparedness and Prevention," 40 CFR 264, Subpart C & A & $\begin{array}{l}\text { Applies to a facility staging, storing, or treating hazardous waste prior to } \\
\text { transfer to the ICDF or an off-Site facility. }\end{array}$ \\
\hline $\begin{array}{l}\text { "Contingency Plan and Emergency Procedures," } \\
40 \text { CFR 264, Subpart D }\end{array}$ & A & $\begin{array}{l}\text { Applies to a facility staging, storing, or treating hazardous waste prior to } \\
\text { transfer to the ICDF or an off-Site facility. }\end{array}$ \\
\hline $\begin{array}{l}\text { "Disposal or Decontamination of Equipment, Structures, } \\
\text { and Soils," } 40 \text { CFR } 264.114\end{array}$ & A & $\begin{array}{l}\text { Applies to contaminated equipment used to remove, treat, or transport } \\
\text { hazardous waste. }\end{array}$ \\
\hline $\begin{array}{l}\text { "Use and Management of Containers," } \\
40 \text { CFR 264.171-178 }\end{array}$ & A & $\begin{array}{l}\text { Applies to containers used during the removal and treatment of hazardous } \\
\text { waste. }\end{array}$ \\
\hline \multicolumn{3}{|l|}{ Land Disposal Restrictions } \\
\hline \multicolumn{3}{|c|}{ IDAPA 58.01.05.011, "Land Disposal Restrictions," and the following, as cited in it: } \\
\hline $\begin{array}{l}\text { "Applicability of Treatment Standards," } \\
40 \text { CFR } 268.40(\mathrm{a})(\mathrm{b})(\mathrm{e})\end{array}$ & A & $\begin{array}{l}\text { Applies to hazardous waste and secondary waste, if treatment is necessary to } \\
\text { meet the disposal facility's WAC or if treatment is required before } \\
\text { placement. }\end{array}$ \\
\hline $\begin{array}{l}\text { "Treatment Standards for Hazardous Debris," } \\
40 \text { CFR } 268.45\end{array}$ & A & $\begin{array}{l}\text { Applies to hazardous debris, if treatment is necessary to meet the disposal } \\
\text { facility's WAC or if treatment is required before placement. }\end{array}$ \\
\hline "Universal Treatment Standards," 40 CFR 268.48(a) & A & $\begin{array}{l}\text { Applies to nondebris hazardous waste and secondary waste, if treatment is } \\
\text { necessary to meet the disposal facility's WAC or if treatment is required } \\
\text { before placement. }\end{array}$ \\
\hline $\begin{array}{l}\text { "Alternative LDR Treatment Standards for Contaminated } \\
\text { Soil," } 40 \text { CFR 268.49 }\end{array}$ & A & $\begin{array}{l}\text { Applies to contaminated soil, if treatment is necessary to meet the disposal } \\
\text { facility's WAC or if treatment is required before placement. }\end{array}$ \\
\hline \multicolumn{3}{|l|}{ Idaho Groundwater Quality Rules } \\
\hline “Ground Water Quality Rule,” IDAPA 58.01.011 & A & $\begin{array}{l}\text { The waste-handling activities must prevent migration of contaminants from } \\
\text { the facility that would cause the Snake River Plain Aquifer groundwater to } \\
\text { exceed applicable State of Idaho groundwater quality standards in } 2095 \text { and } \\
\text { beyond. }\end{array}$ \\
\hline
\end{tabular}


Table 2. (continued).

\begin{tabular}{|c|c|c|}
\hline Requirement (Citation) & $\begin{array}{l}\text { ARAR } \\
\text { Type }\end{array}$ & Comments \\
\hline \multicolumn{3}{|l|}{$T S C A$} \\
\hline $\begin{array}{l}\text { "Polychlorinated Biphenyls (PCBS) Manufacturing, } \\
\text { Processing, Distribution in Commerce, and Use Prohibitions," } \\
40 \text { CFR } 761\end{array}$ & A & $\begin{array}{l}\text { Applicable to removal, decontamination, storage, and disposal of items } \\
\text { (including equipment) with PCB contamination. }\end{array}$ \\
\hline \multicolumn{3}{|l|}{ Solid Waste Management Rules } \\
\hline $\begin{array}{l}\text { IDAPA 58.01.06.012, Solid Waste Management Rules for } \\
\text { Tier II Landfills }\end{array}$ & A & Applicable to operation and management of TAN demolition landfill. \\
\hline \multicolumn{3}{|l|}{ To-be-Considered Requirements } \\
\hline $\begin{array}{l}\text { "Radiation Protection of the Public and the Environment," } \\
\text { DOE Order } 5400.5 \text {, Chapter } \operatorname{II}(1)(\mathrm{a}, \mathrm{b})\end{array}$ & $\mathrm{TBC}$ & $\begin{array}{l}\text { Applies. Substantive design and construction requirements would be met to } \\
\text { keep public exposures as low as reasonably achievable. }\end{array}$ \\
\hline $\begin{array}{l}\text { Region } 10 \text { Final Policy on the Use of Institutional Controls } \\
\text { at Federal Facilities, (EPA 2006b) }\end{array}$ & TBC & Applies to residual waste following completion of the removal action. \\
\hline $\begin{array}{l}\text { A }=\text { applicable requirement } \\
\text { ARAR = applicable or relevant and appropriate requirement } \\
\text { CFR = Code of Federal Regulations } \\
\text { DOE = Department of Energy } \\
\text { EPA = Environmental Protection Agency } \\
\text { ICDF = Idaho CERCLA Disposal Facility } \\
\text { IDAPA = Idaho Administrative Procedures Act }\end{array}$ & \multicolumn{2}{|r|}{$\begin{array}{l}\text { LDR }=\text { land disposal restriction } \\
\text { PCB }=\text { polychlorinated biphenyl } \\
\text { RCRA = Resource Conservation and Recovery Act } \\
\text { TAN }=\text { Test Area North } \\
\text { TBC }=\text { to be considered } \\
\text { TSCA = Toxic Substances Control Act }\end{array}$} \\
\hline
\end{tabular}




\section{PROJECT SCHEDULE}

This removal action is expected to begin in spring 2007 with anticipated completion by spring 2008. These are baseline dates and the project will continue to look for opportunities to safely accelerate work where appropriate to perform more efficiently. A schedule for the removal action is provided in Table 3.

Table 3. Schedule for the removal action.

\begin{tabular}{ll}
\multicolumn{1}{c}{ Activities } & \multicolumn{1}{c}{ Completion Date } \\
\hline Complete Pool Area Demolition & September 2007 \\
Complete Administration Area Demolition & October 2007 \\
Complete Hot Shop Demolition & March 2008 \\
\hline
\end{tabular}

\section{PROJECT COST}

The cost of the alternatives is based on detailed cost estimates (see Table 4). These estimates do not include general and administrative costs and are based on 2006 dollars with no escalation. These estimates include direct costs such as labor, fringe, materials, equipment, supplies, and subcontracts. Alternative 1 will not eliminate, reduce, or control potential risks to human health and the environment. DOE Idaho is required by federal orders and state and federal laws to protect workers and the public from unacceptable exposures. The INL currently has administrative and physical controls in place to prevent unacceptable exposures to ionizing radiation and other chemical hazards from contaminated materials. DOE Idaho cannot implement a "No Action alternative" (i.e., no administrative or physical controls) because it will put workers and the public at risk and will not meet the requirements of federal orders and state and federal laws. Alternative 1, the No Action alternative, cannot be considered a viable alternative and, as such, a cost estimate has not been prepared.

Table 4. Cost estimates for alternatives.

\begin{tabular}{ccc}
\hline Cost Description & Alternative 2 & Alternative 3 \\
\hline $\begin{array}{c}\text { TAN-607 Deactivation and placing in a long } \\
\text { term stable condition }\end{array}$ & $\$ 1,476,979$ & Not applicable \\
\hline $\begin{array}{c}\text { Immediate TAN-607 Decommissioning and } \\
\text { Demolition }\end{array}$ & Not applicable & $\$ 33,724,553$ \\
$\begin{array}{l}\text { Continued Surveillance and Monitoring } \\
\text { Until 2095 (quarterly @ \$100,587/year) }\end{array}$ & $\$ 9,052,032$ & Not applicable \\
Final Demolition of TAN-607 Post-2095 & $\$ 32,247,574$ & Not applicable \\
(2006 dollars) & & \\
Total (2006 dollars) & $\$ 42,776,585$ & $\$ 33,724,553$ \\
\hline
\end{tabular}


The cost estimates cited in Table 4 are based upon performing the work associated with the proposed actions over the next calendar year, until 2095, and post-2095. The cost estimate cited for Alternative 2 assumes that the facility will be maintained in a cold, dark, and dry configuration and condition through at least Fiscal Year 2095 and that demolition will not begin till at least 2095.

\section{EXPECTED CHANGE SHOULD ACTION BE DELAYED OR NOT TAKEN}

The expected change to the decommissioning of TAN-607 Hot Shop Area, should action be delayed or no action taken would be that the facility would remain as it is today. However, because the facility would continue to age, the potential exists that water from rain and snowmelt contribute to contaminated material being released to the subsurface at an increasing frequency with time. Although the potential is low, contaminants, such as PCBs and the longer half-life isotopes in TAN-607 Hot Shop Area, could migrate to the aquifer. If the action is not taken at this time, greater surveillance and maintenance costs would be incurred during the time interval before final decommissioning activities can be performed.

\section{STATUTORY AND REGULATORY AUTHORITY}

Decommissioning the TAN-607 Hot Shop Area is consistent with the joint DOE and U.S. Environmental Protection Agency (EPA) Policy on Decommissioning of Department of Energy Facilities Under the Comprehensive Environmental Response, Compensation and Liability Act, which establishes the CERCLA NTCRA process as the preferred approach for decommissioning surplus DOE facilities. Under this policy, a NTCRA may be taken when DOE determines that the action will prevent, minimize, stabilize, or eliminate a risk to human health and/or the environment. When DOE determines that a CERCLA NTCRA is necessary, DOE is authorized to evaluate, select, and implement the removal action that DOE determines is most appropriate to address the potential risk posed by the release or threat of release. The proposed removal action is being undertaken by DOE Idaho, as lead agency, pursuant to CERCLA Section 104 (a), Executive Order 12580, as recognized by Section 5.3 the Federal Facility Agreement and Consent Order for the Idaho National Engineering Laboratory (DOE-ID 1991). In accordance with 40 CFR 300.415(j) and DOE guidance, on-Site removal actions conducted under CERCLA are required to meet ARARs to the extent practicable considering the exigencies of the situation. The DOE Idaho will comply with the ARARs and "to-be-considered" guidance as set forth in Section 4.4.

\section{OUTSTANDING POLICY ISSUES}

There are no outstanding policy issues.

\section{ENFORCEMENT}

DOE Idaho is conducting this removal action as the lead agency under the authority of 40 CFR 300.5, "Definitions," and 40 CFR 300.415 (b)(1), "Removal Action."

\section{RECOMMENDATION}

This decision document represents the selected removal action for TAN-607 Hot Shop Area at the TAN TSF developed in accordance with CERCLA as amended, and consistent with the NCP. This decision is based on the Administrative Record for the Site. 
Conditions at this site meet the NCP section 40 CFR 300.415(b)(2) criteria for a removal and are recommended for approval of the proposed action.

The recommended action is to perform Alternative 3. The recommended alternative meets the proposed removal action objectives regarding long-term risk, minimizes short-term worker risk and radiation exposure, is cost-effective, and provides a safe and stable configuration that is environmentally sound. DOE Idaho also considers Alternative 3 to be consistent with the remedial action objectives of the Record of Decision Amendment for the V-Tanks (TSF-09 and TSF-18) and Explanation of Significant Differences for the PM-2A Tanks (TSF-26) and TSF-06, Area 10, at Test Area North, Operable Unit 1-10 (DOE-ID 2004a) and compliant with the ARARs.

\section{PUBLIC PARTICIPATION}

The public participation period for the TAN-607 Hot Shop Area EE/CA was from February 7, 2007, through March 11, 2007. A public notice was sent to nine different Idaho and Wyoming newspapers on February 7, 2007; the notice was posted in the DOE Administrative Record electronically, and hard copies of the document were sent to the DOE Public Reading rooms in Idaho Falls and Boise. Comments were received from the public and addressed in the Responsiveness Summary, which is Appendix A of this Action Memorandum.

\section{REFERENCES}

40 CFR 61.92, 2006, "Standard," Code of Federal Regulations, Office of the Federal Register, July 2006.

40 CFR 61.93, 2006, "Emission Monitoring and Test Procedures," Code of Federal Regulations, Office of the Federal Register, July 2006.

40 CFR 61.94, 2006, "Compliance and Reporting," Code of Federal Regulations, Office of the Federal Register, July 2006.

40 CFR 61.145, 2006, "Standard for Demolition and Renovation," Code of Federal Regulations, Office of the Federal Register, July 2006.

40 CFR 262.11, 2006, "Hazardous Waste Determination," Code of Federal Regulations, Office of the Federal Register, July 2006.

40 CFR 264.15, 2006, "General Inspection Requirements," Code of Federal Regulations, Office of the Federal Register, July 2006.

40 CFR 264.114, 2006, "Disposal or Decontamination of Equipment, Structures and Soils," Code of Federal Regulations, Office of the Federal Register, July 2006.

40 CFR 264.171, 2006, "Condition of Containers," Code of Federal Regulations, Office of the Federal Register, July 2006.

40 CFR 264.172, 2006, "Compatibility of Waste with Containers," Code of Federal Regulations, Office of the Federal Register, July 2006.

40 CFR 264.173, 2006, "Management of Containers," Code of Federal Regulations, Office of the Federal Register, July 2006. 
40 CFR 264.174, 2006, "Inspections," Code of Federal Regulations, Office of the Federal Register, July 2006.

40 CFR 264.175, 2006, “Containment," Code of Federal Regulations, Office of the Federal Register, July 2006.

40 CFR 264.176, 2006, "Special Requirements for Ignitable or Reactive Waste," Code of Federal Regulations, Office of the Federal Register, July 2006.

40 CFR 264.177, 2006, "Special Requirements for Incompatible Wastes," Code of Federal Regulations, Office of the Federal Register, July 2006.

40 CFR 264.178, 2006, “Closure," Code of Federal Regulations, Office of the Federal Register, July 2006.

40 CFR 264.553, 2006, “Temporary Units (TU)," Code of Federal Regulations, Office of the Federal Register, July 2006.

40 CFR 264.554, 2006, "Staging Piles," Code of Federal Regulations, Office of the Federal Register, July 2006.

40 CFR 264, Subpart C, 2006, "Preparedness and Prevention," Code of Federal Regulations, Office of the Federal Register, July 2006.

40 CFR 264, Subpart D, 2006, "Contingency Plan and Emergency Procedures," Code of Federal Regulations, Office of the Federal Register, July 2006.

40 CFR 268.40, 2006, “Applicability of Treatment Standards," Code of Federal Regulations, Office of the Federal Register, July 2006.

40 CFR 268.45, 2006, “Treatment Standards for Hazardous Debris," Code of Federal Regulations, Office of the Federal Register, July 2006.

40 CFR 268.48, 2006, "Universal Treatment Standards," Code of Federal Regulations, Office of the Federal Register, July 2006.

40 CFR 268.49, 2006, “Alternative LDR Treatment Standards for Contaminated Soil," Code of Federal Regulations, Office of the Federal Register, July 2006.

40 CFR 300, 2006, "National Oil and Hazardous Substances Pollution Contingency Plan," Code of Federal Regulations, Office of the Federal Register, August 2006.

40 CFR 300.415, 2006, "Removal Action," Code of Federal Regulations, Office of the Federal Register, August 2006.

40 CFR 761.62, 2006, “Disposal of PCB Bulk Product Waste," Code of Federal Regulations, Office of the Federal Register, June 2006.

40 CFR 761.79, 2006, "Decontamination Standards and Procedures," Code of Federal Regulations, Office of the Federal Register, June 2006.

16 USC $§ 470$ et seq., 1966, "National Historic Preservation Act," United States Code, October 15, 1966. 
42 USC § 9601 et seq., 1980, “Comprehensive Environmental Response, Compensation and Liability Act of 1980 (CERCLA/Superfund)," United States Code, December 11, 1980.

42 USC § 9621, 1998, “Cleanup Standards,” United States Code, January 26, 1998.

DOE O 5400.5, 1993, "Radiation Protection of the Public and the Environment," Change 2, U.S. Department of Energy, January 7, 1993.

DOE, 1995, Department of Energy Programmatic Spent Nuclear Fuel Management and Idaho National Engineering Laboratory Environmental Restoration and Waste Management Programs Final Environmental Impact Statement, DOE/EIS-0203-F, U.S. Department of Energy, April 1995.

DOE and EPA, 1995, Policy on Decommissioning of Department of Energy Facilities Under the Comprehensive Environmental Response, Compensation, and Liability Act (CERCLA), KLF-211-95, Rev. 0, U.S. Department of Energy, Washington, D.C., and U.S. Environmental Protection Agency, Washington, D.C., May 22, 1995.

DOE and SHPO, 2005, "Memorandum of Agreement Between the United States Department of Energy, Idaho Operations Office, and the Idaho State Historic Preservation Office," Record No. 2080874, U.S. Department of Energy Idaho Operations Office, October 27, 2005.

DOE-ID, 1991, Federal Facility Agreement and Consent Order for the Idaho National Engineering Laboratory, Administrative Docket No. 1088-06-120, U.S. Department of Energy Idaho Operations Office; U.S. Environmental Protection Agency, Region 10; Idaho Department of Health and Welfare, December 9, 1991.

DOE-ID, 1999, Hazardous Waste Management Act Closure Plan for the Process Experimental Pilot Plant Incinerator and Waste Stabilization Units, DOE/ID-10525, Rev. 1, January 1999.

DOE-ID, 2004a, Record of Decision Amendment for the V-Tanks (TSF-09 and TSF-18) and Explanation of Significant Differences for the PM-2A Tanks (TSF-26) and TSF-06, Area 10, at Test Area North, Operable Unit 1-10, DOE/ID-10682 Amend, Rev. 0, U.S. Environmental Protection Agency, Idaho Department of Environmental Quality, U.S. Department of Energy Idaho Operations Office, February 2004.

DOE-ID, 2004b, In Situ Bioremediation Remedial Action Work Plan for Test Area North Final Groundwater Remediation, Operable Unit 1-07B, DOE/ID-11015, Rev. 2, U.S. Department of Energy Idaho Operations Office, July 2004.

DOE-ID, 2004c, HWMA/RCRA Closure Plan for the TAN/TSF Intermediate-Level Radioactive Waste Management System, Phase I: Treatment Subsystem (TAN-616), DOE/ID-11021, Rev. 2, U.S. Department of Energy Idaho Operations Office, January 2004.

DOE-ID, 2005, Idaho National Engineering and Environmental Laboratory Cultural Resource Management Plan, DOE/ID-10997, Rev. 1, U.S. Department of Energy Idaho Operations Office, September 2005.

DOE, 2007, "Engineering Evaluation/Cost Analysis (EE/CA) for Decommissioning of TAN-607: Hot Shop Area," DOE/ID-11302, Idaho National Laboratory, Idaho Cleanup Project, February 2007. 
EDF-7595, 2006, "Radiological Source Term for the TAN-607 Maintenance and Assembly Area Engineering Evaluation/Cost Analysis," Rev. 0, Idaho National Laboratory, Idaho Cleanup Project, December 2006.

EDF-7515, 2006, “Groundwater Assessment for TAN 607: Hot Shop Area,” Rev. 0, Idaho National Laboratory, Idaho Cleanup Project, December 2006.

EDF-7538, "Soil Risk Assessment for TAN-607: Hot Shop Area," Rev. 0, Idaho National Laboratory, Idaho Cleanup Project, December 2006.

EPA, 1993, Guidance on Conducting Non-Time Critical Removal Actions Under CERCLA, EPA/540-R-93-057, U.S. Environmental Protection Agency, August 1993.

EPA, 2006a, Preliminary Remediation Goals, http://www.epa.gov/region9/waste/sfund/prg/index.html, U.S. Environmental Protection Agency, Web page updated August 17, 2006, Web page visited September 13, 2006.

EPA, 2006b, Region 10 Final Policy on the Use of Institutional Controls at Federal Facilities, U.S. Environmental Protection Agency, May 2006.

Executive Order 12580, 1987, "Superfund Implementation," Office of the President, January 23, 1987.

ICP, 2005, TAN-616 HWMA/RCRA Closure Risk Assessment for Environmental Media Beneath the TAN-607 Decontamination Room Sump, ICP/EXT-05-00899, Rev. 1, Idaho National Laboratory, Idaho Cleanup Project, October 2005.

IDAPA 58.01.01.161, 1995, "Toxic Substances," Idaho Administrative Procedures Act, Idaho Department of Environmental Quality, June 30, 1995.

IDAPA 58.01.01.650, 1994, "Rules for Control of Fugitive Dust," Idaho Administrative Procedures Act, Idaho Department of Environmental Quality, May 1, 1994.

IDAPA 58.01.01.651, 1994, "General Rules," Idaho Administrative Procedures Act, Idaho Department of Environmental Quality, May 1, 1994.

IDAPA 58.01.05.006, 2006, "Standards Applicable to Generators of Hazardous Waste," Idaho Administrative Procedures Act, Idaho Department of Environmental Quality, April 11, 2006.

IDAPA 58.01.05.008, 2006, "Standards for Owners and Operators of Hazardous Waste Treatment, Storage, and Disposal Facilities," Idaho Administrative Procedures Act, Idaho Department of Environmental Quality, April 11, 2006.

IDAPA 58.01.05.011, 2006, “Land Disposal Restrictions," Idaho Administrative Procedures Act, Idaho Department of Environmental Quality, April 11, 2006.

IDAPA 58.01.06.012, 2003, “Applicable Requirements for Tier II Facilities,” Idaho Administrative Procedures Act, Idaho Department of Environmental Quality, April 3, 2003

IDAPA 58.01.011, 1997, "Ground Water Quality Rule," Idaho Administrative Procedures Act, Idaho Department of Environmental Quality, March 20, 1997. 
INEL, 1995, Background Dose Equivalent Rates and Surficial Soil Metal and Radionuclide Concentrations for the Idaho National Engineering Laboratory, INEL-94/0250, Rev. 0, February 1995.

Public Law 99-499, 1986, "Superfund Amendments and Reauthorization Act of 1986 (SARA)," 100 Statutes 1728, Public Law, October 17, 1986.

Stacy, S, 2005, Historical American Engineering Record, Idaho National Engineering and Environmental Laboratory, Test Area North, INEEL/EXT-04-02536, Historic American Engineering Record No. ID-33-E, National Park Service, February 2005. 
Appendix A

\section{Responses to Significant Comments on the TAN-607 Hot Shop Area Decommissioning}




$$
\text { A-2 }
$$




\section{Appendix A}

\section{Responses to Significant Comments on the TAN-607 Hot Shop Area Decommissioning}

\begin{tabular}{|c|c|c|}
\hline $\begin{array}{l}\text { Comment } \\
\text { No. }\end{array}$ & Comment/Issue & Resolution \\
\hline 1 & $\begin{array}{l}\text { Alternative } 3 \text { would be the best for the State of Idaho, the } \\
\text { aquifer, site employees and residents of the state. } \\
\text { Mike Oar }\end{array}$ & Thank you for your comment. \\
\hline 2 & $\begin{array}{l}\text { The best option is Alternative } 2 \text {. The TAN Hot Shop has } \\
\text { always been one of those facilities that has been hard to } \\
\text { justify for long period of time. However, when needed, no } \\
\text { other facility will do the job. It was almost closed down } \\
\text { until it was needed for evaluation of SL-1 debris. Likewise, } \\
\text { it was almost shut down until Three Mile Island accident } \\
\text { occurred. At tat time, evaluations of the entire DOE } \\
\text { Complex proved that there was no other facility capable of } \\
\text { handling evaluation of accident debris and storing the core. } \\
\text { With renewed interest in Nuclear Power research, the Hot } \\
\text { Shop can add much to research and development of reactor } \\
\text { concepts. The shielding in the facility is such that entire } \\
\text { reactor concepts can be tested and quickly modified. } \\
\text { Replacement of the facility will require decades and cost } \\
\text { billions of dollars. } \\
\text { Therefore, the best alternative is to support the facility at the } \\
\text { minimum cost until the next mission comes along. } \\
\text { I have reviewed the EE/CA for the "Hot Shop" } \\
\text { Arnold L. Ayers, Jr. }\end{array}$ & $\begin{array}{l}\text { Thank you for your comment. Despite significant } \\
\text { efforts by the United States (U.S.) Department of } \\
\text { Energy (DOE) to secure new business, no future } \\
\text { mission has been identified for the TAN-607 Hot } \\
\text { Shop Area. Its disposition has been agreed to by } \\
\text { the Idaho State Historical Preservation Office } \\
\text { documented in the Memorandum of Agreement } \\
\text { signed October } 2005 \text { and it is therefore } \\
\text { considered a surplus facility. A key element in } \\
\text { DOE's strategy for surplus facilities is } \\
\text { decommissioning to the maximum extent possible } \\
\text { to ensure risk and building footprint reduction } \\
\text { and thereby eliminating operations and } \\
\text { maintenance cost. In addition, the DOE's } 2006 \\
\text { Strategic Plan is "complete cleanup of the } \\
\text { contaminated nuclear weapons manufacturing } \\
\text { and testing sites across the United States. DOE is } \\
\text { responsible for the risk reduction and cleanup of } \\
\text { the environmental legacy of the Nation's nuclear } \\
\text { weapons program, one of the largest, most } \\
\text { diverse, and technically complex environmental } \\
\text { programs in the world. The Department will } \\
\text { successfully achieve this strategic goal by } \\
\text { ensuring the safety of the DOE employees and }\end{array}$ \\
\hline
\end{tabular}




\begin{tabular}{|c|c|c|}
\hline $\begin{array}{c}\text { Comment } \\
\text { No. }\end{array}$ & Comment/Issue & Resolution \\
\hline & & $\begin{array}{l}\text { U.S. citizens, acquiring the best resources to } \\
\text { complete the complex tasks, and managing } \\
\text { projects throughout the United States in the most } \\
\text { efficient and effective manner." }\end{array}$ \\
\hline 3 & $\begin{array}{l}\text { I have reviewed the EE/CA for the "Hot Shop" demolition } \\
\text { and agree with the findings in favor of the choice for } \\
\text { alternative } 3 \text {. } \\
\text { Thank you, Richard Malloy }\end{array}$ & Thank you for your comment. \\
\hline 4 & $\begin{array}{l}\text { We are already doing demolition on Tan-607 Hot Shop. I'm } \\
\text { working on it, your comment from the public is a little late. } \\
\text { Fran Blake }\end{array}$ & $\begin{array}{l}\text { The activities taking place in the TAN Hot Shop Area at this } \\
\text { time are deactivation and decontamination that are covered } \\
\text { under the General Site-Wide EE/CA, the TAN-607A area is } \\
\text { actually under decommissioning and demolition which were } \\
\text { previously available for public review and comment.. }\end{array}$ \\
\hline 5 & $\begin{array}{l}\text { Page 8-9. I don't think the abbreviation "Ci" is defined } \\
\text { anywhere. We know it means Curries. Also, if I were a } \\
\text { member of the general community, should I be concerned or } \\
\text { relieved that the unit has } 77 \mathrm{Ci} \text { ? This number needs to be put } \\
\text { in perspective. On page } 9 \text {, the letter "E" is not defined. I } \\
\text { assume it is = 10. Also, I would not use scientific number } \\
\text { notation in a public document. Actually, almost all the } \\
\text { Curries are in } 2-4 \text { isotopes. I would lump all the rest into "all } \\
\text { other". There is a typo on the 4th line. } \\
\text { p } 13 \text { I think a residence at the site in } 2095 \text { is an unlikely } \\
\text { event for comparison purposes. } \\
\text { p } 14 \text {. Should the public be alarmed that Pu- } 239 \text { is about } 5 \\
\text { times over the spec? }\end{array}$ & $\begin{array}{l}\text { The acronym "Ci" (curie) has been included in the acronym } \\
\text { list. The } 77 \text { curies is bound as fixed contamination and is of } \\
\text { no concern to the general public, greater than } 99 \% \text { of the } \\
\text { curies will be disposed of in the ICDF or an off-site facility. } \\
\text { The letter "E" is referring to scientific notation when } \\
\text { displaying figures (i.e. } 5.99 E-02=0.0599 \text { curies), this is the } \\
\text { standard method of displaying a number to the }+ \text { - power of } \\
\text { 10. This clarification will be added to Table } 1 \text { in the Action } \\
\text { Memorandum. There are several daughter products of many } \\
\text { of the given isotopes that are reflected in the table, some have } \\
\text { varying half-life, solubility's, etc. Some of these isotopes and } \\
\text { their daughters are of more concern to groundwater modeling } \\
\text { than others due to the half-life. } \\
\text { The residential scenario for the INL in } 2095 \text { was established }\end{array}$ \\
\hline
\end{tabular}




\begin{tabular}{|c|c|c|}
\hline $\begin{array}{c}\text { Comment } \\
\text { No. }\end{array}$ & Comment/Issue & Resolution \\
\hline & $\begin{array}{l}\text { p } 18 \text { Since many members of the community will have } \\
\text { friends or relatives at the D\&D, what worker exposure } \\
\text { (mmrems or mmrems/hr) do you expect? I would like to see } \\
\text { more how you intend to minimize this. This was a big deal } \\
\text { on the ETR EE/CA. } \\
\text { p } 21 \text { Economics. Most of my concerns on this table were in } \\
\text { my letter. A time period of } 90 \text { years does not seem to a } \\
\text { meaningful period, when this decision could be looked at } \\
\text { again every year. The longest time period I would ever use } \\
\text { would be } 25 \text { years or one generation. I would like to see an } \\
\text { estimate of yearly standby costs (separated) to determine if } \\
\text { they are a significant penalty. A breakdown (Labor, } \\
\text { Materials, etc.) of the huge } \$ 32 \text { MM estimate would give the } \\
\text { reader confidence that this is a reasonable number. The } \\
\text { reason I bring this up is that cost overruns can lead to } \\
\text { significant delays (Hanford) or that the D\&D is never } \\
\text { finished. Finally, given the quality of the estimates, I suspect } \\
8 \text { significant figures in not warranted. } \\
\text { I hope you found these comments helpful. } \\
\text { Doug Weir }\end{array}$ & $\begin{array}{l}\text { through agreements with EPA Region X as a point of } \\
\text { consistency amongst the facilities. The Land Use Plan for the } \\
\text { INEEL in } 1995 \text { indicated the Department of Energy would } \\
\text { maintain control of the site for at least the next } 100 \text { years, this } \\
\text { also allows risk calculations to be set as the minimum } \\
\text { radioactive contaminant concentration to be established that } \\
\text { would allow isotopes to decay to less than } 1 \text { in } 1,000,000 \\
\text { cancer risk by } 2095 \text {. } \\
\text { The maximum risk for human health for Pu-239 at the end of } \\
\text { the Institutional Control period is } 2 E-07, \text { which is less than } \\
\text { the EPA established } 1 E-06 \text { cancer risk scenario. Table } 4 \text { on } \\
\text { page } 14 \text { is referring to the Ecological Based Screening Level } \\
\text { (EBSL), which is the risk to certain plants and animals. There } \\
\text { should be no concern to the public. } \\
\text { Although the DOE annual limit for radiation workers is set at } \\
5 \text { Rem per year (5000 mR), the INL administrative limit is set } \\
\text { at } 700 \text { mR per year, which includes all D\&D workers. It is } \\
\text { unlikely that the work at TAN will cause a worker to reach } \\
700 \text { mR. This is minimized through our ALARA (as low as } \\
\text { reasonably achievable) process and other D\&D specific work } \\
\text { practices. } \\
\text { The period of } 90 \text { years is the remaining time left in the DOE } \\
\text { Institutional Control period for the INL. The cost estimate in } \\
\text { the Action Memorandum now includes an estimate of } \\
\$ 100,587 \text { per year right after "Continued Surveillance and } \\
\text { Monitoring" on Table } 4 \text {. } \\
\text { Your comments were very helpful, thank you. }\end{array}$ \\
\hline
\end{tabular}




\section{Appendix B}

\section{Citizens Advisory Board Comments}

No comments from the Citizens Advisory Board. 
B-2 


\section{Appendix C}

\section{Shoshone-Bannock Tribes' Comments}

No comments from the Shoshone-Bannock Tribes. 


$$
\text { C-2 }
$$

